\title{
A Highly Active and Selective Manganese Oxide Promoted Cobalt-on-Silica Fischer-Tropsch Catalyst
}

\author{
Johan P. den Breejen • Anne M. Frey • Jia Yang • Anders Holmen • \\ Matti M. van Schooneveld • Frank M. F. de Groot • \\ Odile Stephan · Johannes H. Bitter · Krijn P. de Jong
}

Published online: 11 August 2011

(C) The Author(s) 2011. This article is published with open access at Springerlink.com

\begin{abstract}
A highly active and selective manganese oxidepromoted silica-supported cobalt catalyst for the FischerTropsch reaction is reported. $\mathrm{Co} / \mathrm{MnO} / \mathrm{SiO}_{2}$ catalysts were prepared via impregnation of a cobalt nitrate and manganese nitrate precursor, followed by drying and calcination in an NO/He flow. The catalysts were studied with STEMEELS, infrared spectroscopy measurements of adsorbed $\mathrm{CO}$ and Steady-State Isotopic Transient Kinetic Analysis experiments. Based on those experiments, a relation between $\mathrm{C}_{5+}$-selectivity and surface-coverages of $\mathrm{CH}_{x^{-}}$ intermediates on cobalt was found.
\end{abstract}

Electronic supplementary material The online version of this article (doi:10.1007/s11244-011-9703-0) contains supplementary material, which is available to authorized users.

J. P. den Breejen · A. M. Frey · M. M. van Schooneveld .

F. M. F. de Groot · J. H. Bitter · K. P. de Jong ( $\varangle)$

Department of Inorganic Chemistry and Catalysis, Debye

Institute for NanoMaterials Science, Utrecht University,

NL-3584 CA Utrecht, The Netherlands

e-mail: K.P.deJong@uu.nl

Present Address:

J. P. den Breejen

Shell Global Solutions International B.V., Amsterdam,

The Netherlands

J. Yang $\cdot$ A. Holmen

Department of Chemical Engineering, Norwegian University

of Science and Technology (NTNU), N-7491 Trondheim,

Norway

O. Stephan

Laboratoire de Physique des Solides, Université Paris-Sud,

91405 Orsay cedex, France
Keywords Fischer-Tropsch - Cobalt on silica . Manganese promotion - NO calcination - STEM-EELS . CO adsorption $\cdot$ Infrared Spectroscopy $\cdot$ SSITKA

\section{Introduction}

Cobalt catalysts are extensively studied and widely applied in the Fischer-Tropsch (FT) reaction. In this reaction synthesis gas $\left(\mathrm{CO} / \mathrm{H}_{2}\right)$ is converted into hydrocarbons, which can be used as transportation fuel. Synthesis gas can be obtained from various sources as natural gas, coal and biomass, showing the relevance of the FT reaction.

To enhance the activity of an FT catalyst per unit weight of cobalt, the latter is commonly dispersed on a support material to enhance its surface-to-volume ratio by decreasing the cobalt particle size to an optimal value of 5-6 nm. [1-4] A recent example of improving the catalytic activity using this methodology is provided in a previous contribution from our laboratory, where a cobalt-on-silica catalyst was synthesized by an impregnation and drying step, followed by calcination of cobalt nitrate precursor in a flow of NO/He [5, 6]. This method yielded a surfaceweighted cobalt particle size of $\sim 5 \mathrm{~nm}$ with a narrow particle size distribution. As a result of that, a highly active $\left(4.8 \cdot 10^{-5} \mathrm{~mol}_{\mathrm{Co}} \cdot \mathrm{g}_{\mathrm{Co}} \cdot \mathrm{s}^{-1}\right.$ at $220{ }^{\circ} \mathrm{C}$ and 1 bar $) \mathrm{FT}$ catalyst was obtained, however, accompanied by a moderate $\mathrm{C}_{5+^{-}}$ selectivity (32 wt $\%)$.

Aim of this study is to enhance the $\mathrm{C}_{5+}$-selectivity of these small Co particles while maintaining their high activity. This was pursued by the addition of a metal oxide promoter. Various metal oxides have been used for selectivity promotion in FT catalysis, as has been reviewed by several authors [7-10]. In the current study manganese oxide was chosen. Examples of the effectiveness of this 
oxide in increasing the $\mathrm{C}_{5+}$-selectivity in the cobalt catalyzed FT reaction have been reported [11-23]. As an example, a study from Bezemer et al. [21] showed an increase in $\mathrm{C}_{5+}$-selectivity from 31 to $45 \mathrm{wt} \%$ for a cobalt on carbon nanofiber catalyst upon the addition of $\mathrm{MnO}$ at an $\mathrm{Mn} / \mathrm{Co}$ atomic ratio of 0.03 . In that case $\mathrm{MnO}$ was added via an aqueous impregnation of manganese nitrate on a reduced and passivated $\mathrm{Co} / \mathrm{CNF}$ catalyst. As this caused blocking of part of the cobalt surface, the enhancement in $\mathrm{C}_{5+}$-selectivity was accompanied with a decrease in activity, which is generally observed [13-15, 17, 19-22].

In the current paper $\mathrm{MnO}$-promoted $\mathrm{Co} / \mathrm{SiO}_{2}$ catalysts were prepared via co-impregnation using an aqueous solution of manganese nitrate and cobalt nitrate, with $\mathrm{Mn} /$ Co atomic ratios ranging from 0 to 0.25 . After drying, the mixed nitrate samples were calcined in a flow of $1 \mathrm{vol} \%$ $\mathrm{NO} / \mathrm{He}[5,24]$. Please note that this calcination method is key to obtain cobalt particles with a narrow size distribution for the unpromoted $\mathrm{Co} / \mathrm{SiO}_{2}$ catalyst. For comparison, other batches of dried sample were calcined in an air flow. Throughout this study $\mathrm{Pt}$ has been added as a reduction promoter to the catalyst.

The catalysts were characterized using X-Ray diffraction (XRD), Transmission Electron Microscopy (TEM) and Scanning Transmission Electron Microscopy with Electron Energy Loss Spectroscopy (STEM-EELS). To investigate the catalytic effect of $\mathrm{MnO}$, the catalysts were tested in the FT reaction at $220{ }^{\circ} \mathrm{C}, \mathrm{H}_{2} / \mathrm{CO}=2 \mathrm{v} / \mathrm{v}$ and atmospheric pressure. Moreover, room temperature $\mathrm{CO}$ adsorption monitored with infrared (IR) spectroscopy was used to indirectly probe the interaction of the supported cobalt particles and the manganese oxide. [22, 25] In addition, Steady-State Isotopic Transient Kinetic Analysis (SSITKA) was applied to study the amount and residence times of the FT intermediates $\mathrm{CO}$ and $\mathrm{CH}_{x}$ as a function of the amount of $\mathrm{MnO}$ during steady-state $\mathrm{CO}$ hydrogenation at $210^{\circ} \mathrm{C}$, $\mathrm{H}_{2} / \mathrm{CO}=10 \mathrm{v} / \mathrm{v}$ and 1.85 bar.

\section{Experimental}

\subsection{Preparation}

Silica support material (Grace-Davison Davicat 1454SI silica gel, BET surface area $=500 \mathrm{~m}^{2} \mathrm{~g}^{-1}$, pore volume $=1.1 \mathrm{~mL} \mathrm{~g}^{-1}$ and $6 \mathrm{~nm}$ average pore size) was dried for $12 \mathrm{~h}$ in air at $120{ }^{\circ} \mathrm{C}$ prior to further use. $\mathrm{MnO}$-promoted cobalt catalysts were prepared via a single pore-volume impregnation using an aqueous solution containing $\mathrm{Co}\left(\mathrm{NO}_{3}\right)_{2} \cdot 6 \mathrm{H}_{2} \mathrm{O}, \mathrm{Mn}\left(\mathrm{NO}_{3}\right)_{2} \cdot 6 \mathrm{H}_{2} \mathrm{O}$ and $\mathrm{Pt}\left(\mathrm{NH}_{3}\right)_{4}\left(\mathrm{NO}_{3}\right)_{2}$, aiming for a cobalt metal loading of $17 \mathrm{wt} \%$. Various catalysts were prepared with a $\mathrm{Mn} / \mathrm{Co}$ atomic ratio ranging from 0 to 0.25 . Platinum $(0.05 \mathrm{wt} \%)$ was added in all cases as a reduction promoter via co-impregnation. After impregnation the catalyst was dried for $12 \mathrm{~h}$ at $70{ }^{\circ} \mathrm{C}$, with a heating rate of $1{ }^{\circ} \mathrm{C} \mathrm{min}{ }^{-1}$, in stagnant air. Subsequently, the dried catalyst (100 mg) was calcined for $1 \mathrm{~h}$ at $240{ }^{\circ} \mathrm{C}$ in a $100 \mathrm{~mL} \mathrm{~min}{ }^{-1}$ flow of either 1 vol\% NO in He (NC) or air (AC). The catalysts $(20 \mathrm{mg})$ were reduced prior to FT catalysis with a heating rate of $5{ }^{\circ} \mathrm{C} \cdot \mathrm{min}^{-1}$ at temperatures ranging from $400{ }^{\circ} \mathrm{C}$ to $550{ }^{\circ} \mathrm{C}$ for $2 \mathrm{~h}$, using a flow of $30 \mathrm{vol} \% \mathrm{H}_{2} / \mathrm{He}$

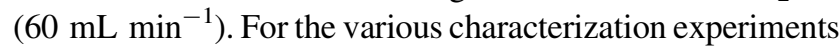
(vide infra) similar reduction conditions were applied, followed by passivation in air at room temperature (rt).

\subsection{Characterization}

XRD analyses were conducted to determine the average crystallite size of the calcined catalyst precursors. The diffraction patterns were recorded by a Bruker-AXS D8 Advance $\mathrm{X}$-ray diffractometer using $\mathrm{Co}-\mathrm{K}_{\alpha}$ radiation ( $\lambda=1.789 \AA$ ) scanning from 10 to $90^{\circ} 2 \theta$. The $\mathrm{Co}_{3} \mathrm{O}_{4}$ crystallite sizes were determined using the Scherrer equation for the (311) peak at $2 \theta=43.1^{\circ}$.

TEM measurements were performed using an FEI Technai 20F. TEM samples were prepared via an ethanol suspension of the passivated catalysts brought onto a carbon film on a copper grid.

STEM-EELS measurements were performed to investigate the spatial distribution of cobalt, manganese and silica in an $\mathrm{AC}$ or an $\mathrm{NC} \mathrm{Co} / \mathrm{MnO} / \mathrm{Pt} / \mathrm{SiO}_{2}$ catalyst $(\mathrm{Mn} / \mathrm{Co}=$ 0.08 at/at). The $\mathrm{Co}$ and $\mathrm{Mn} \mathrm{L}_{2,3}$-edges and the $\mathrm{O} \mathrm{K}$-edge were studied using a $100 \mathrm{keV}$ STEM apparatus (VG HB 501) equipped with a field emission source and parallel Gatan EELS spectrometer [26, 27]. The EELS-spectra were taken with a $0.99 \mathrm{eV}$ energy resolution and a $1 \mathrm{~nm}$ spatial resolution. The reduced $\left(450{ }^{\circ} \mathrm{C}\right)$ and passivated samples were sonicated in ethanol and brought onto a carbon film on a regular copper EM grid.

X-ray Absorption Near-Edge Spectroscopy (XANES) at the Co K-edge was applied to study the degree of reduction of the catalysts. The measurements were done at DESY synchrotron (beamline C) in Hamburg, using a Si (111) double crystal monochromator detuned to $60 \%$ of the maximum intensity to avoid higher harmonics. The catalysts were reduced in situ in a transmission cell in a 30 vol\% $\mathrm{H}_{2}$ in He flow, with a ramp of $5{ }^{\circ} \mathrm{C} \cdot \mathrm{min}^{-1}$ at $450{ }^{\circ} \mathrm{C}$, for $2 \mathrm{~h}$. Prior to a XANES measurement the samples were cooled in the $\mathrm{H}_{2} / \mathrm{He}$ flow to liquid nitrogen temperature. Spectra of $\mathrm{Co}_{3} \mathrm{O}_{4}, \mathrm{CoO}$ and cobalt foil were measured as references. The absorption spectra were analyzed using the XDAP code, as described elsewhere. [28, 29] The degree of reduction was calculated using linear combination analysis of the XANES spectra of the catalysts, $\mathrm{CoO}$ and $\mathrm{Co}$ foil references.

Infrared spectroscopy was used to study the adsorption of $\mathrm{CO}$ on the cobalt catalysts, and investigate the influence 
of $\mathrm{MnO}$ addition. For the IR measurements, passivated catalyst $(5 \mathrm{mg})$ was mixed with silica $(5 \mathrm{mg}$, Davicat silicagel), pressed into a self-supporting wafer ( $\sim 6 \mathrm{mg} \mathrm{cm}^{-2}$ ) and mounted in an IR transmission cell. Prior to the $\mathrm{CO}$ adsorption measurements, the catalysts were re-reduced in an $\mathrm{H}_{2}$ flow $\left(\sim 50 \mathrm{~mL} \mathrm{~min}^{-1}\right)$ at $450{ }^{\circ} \mathrm{C}$ for $2 \mathrm{~h}$. Afterwards, the catalysts were cooled to room temperature. Below $100{ }^{\circ} \mathrm{C}$, the hydrogen flow was stopped, and the cell was evacuated $\left(10^{-6} \mathrm{mbar}\right)$ for $15 \mathrm{~min}$. Subsequently, after the admission of 350 mbar $10 \mathrm{vol} \%$ $\mathrm{CO} / \mathrm{He}$ to the cell, several IR spectra were collected during a period of $30 \mathrm{~min}$ at ambient temperatures.

\subsection{Catalysis}

The FT reaction was performed at $220{ }^{\circ} \mathrm{C}$ at 1 bar in a plug-flow reactor with a $\mathrm{H}_{2} / \mathrm{CO}$ ratio of $2 \mathrm{v} / \mathrm{v}$. Typically $20 \mathrm{mg}$ catalyst $(90-150 \mu \mathrm{m})$, mixed with $200 \mathrm{mg} \mathrm{SiC}$ $(\sim 200 \mu \mathrm{m})$, was loaded in the reactor in order to achieve differential and isothermal plug-flow conditions. The catalysts were reduced in situ in an $\mathrm{H}_{2} / \mathrm{Ar}\left(20 / 40 \mathrm{~mL} \mathrm{~min}^{-1}\right)$ flow at temperatures ranging from 400 to $550{ }^{\circ} \mathrm{C}$ for $2 \mathrm{~h}$, with a ramp of $5^{\circ} \mathrm{C} \min ^{-1}$. Gas chromatographic analysis was performed during the FT reaction to determine the activity or Cobalt-Time-Yield (CTY, $10^{-5} \mathrm{~mol}_{\mathrm{CO}} \cdot \mathrm{g}_{\mathrm{Co}}^{-1} \mathrm{~s}^{-1}$ ) and selectivity (wt\%) towards $\mathrm{C}_{1^{-}}$and $\mathrm{C}_{5+}$-hydrocarbons. The reported activity and selectivity data are obtained after at least $20 \mathrm{~h}$ operation and at 2\% CO conversion level, which was achieved by tuning the gas flow.

The SSITKA experiments were performed as described elsewhere [30]. Typically $100 \mathrm{mg}$ catalyst $(90-150 \mu \mathrm{m})$ was diluted with $200 \mathrm{mg} \mathrm{SiC}(75-150 \mu \mathrm{m})$ and loaded in a plug-flow microreactor. Prior to catalysis, the catalysts were reduced at $450{ }^{\circ} \mathrm{C}$ for $2 \mathrm{~h}$, with a flow of $30 \mathrm{vol} \% \mathrm{H}_{2}$

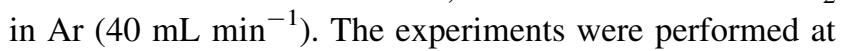
$210{ }^{\circ} \mathrm{C}, 1.85$ bar, with an $\mathrm{H}_{2} / \mathrm{CO}$ ratio of $10 \mathrm{v} / \mathrm{v}$. During steady-state reaction isotopic switches were performed, e.g., from ${ }^{12} \mathrm{CO} / \mathrm{Ar} / \mathrm{H}_{2}$ to ${ }^{13} \mathrm{CO} / \mathrm{Kr} / \mathrm{H}_{2}$. The transients of labeled reactants and products (e.g., ${ }^{13} \mathrm{CO}$ and ${ }^{13} \mathrm{CH}_{4}$ ) were monitored with a Mass Spectrometer (MS). The surface residence times and coverages of $\mathrm{CO}$ and $\mathrm{CH}_{x}$ intermediates were calculated from those transients. A gas chromatograph equipped with FID and TCD was used to determine the $\mathrm{CO}$ conversion.

\section{Results and Discussion}

\subsection{XRD}

In Table 1 the $\mathrm{Co}_{3} \mathrm{O}_{4}$ crystallite sizes of the calcined $\mathrm{Co}(/ \mathrm{MnO}) / \mathrm{Pt} / \mathrm{SiO}_{2}$ catalyst precursors prepared via $\mathrm{NC}$ or $\mathrm{AC}$ with different $\mathrm{Mn} / \mathrm{Co}$ ratios are shown.
Table 1 XRD $\mathrm{Co}_{3} \mathrm{O}_{4}$ crystallite sizes and Co particle size (nm) for $\mathrm{AC}$ and $\mathrm{NC} \mathrm{Co}(/ \mathrm{MnO}) / \mathrm{Pt} / \mathrm{SiO}_{2}$ catalyst precursors with various $\mathrm{Mn} / \mathrm{Co}$ atomic ratios; Co loading is $17 \mathrm{wt} \%$ for all samples

\begin{tabular}{|c|c|c|c|c|}
\hline \multirow[t]{2}{*}{$\mathrm{Mn} / \mathrm{Co}$ ratio (at/at) } & \multicolumn{2}{|c|}{$\begin{array}{l}\mathrm{Co}_{3} \mathrm{O}_{4} \mathrm{XRD} \\
\text { crystallite size }\end{array}$} & \multicolumn{2}{|c|}{$\begin{array}{l}\text { Particle size } \\
\text { (TEM) }\end{array}$} \\
\hline & $\mathrm{AC}$ & $\mathrm{NC}$ & $\mathrm{AC}$ & $\mathrm{NC}$ \\
\hline 0 & 9.7 & 4.7 & 12 & 4.6 \\
\hline 0.06 & 5.8 & 3.3 & - & 3.0 \\
\hline 0.08 & 4.9 & 3.0 & - & - \\
\hline 0.13 & 5.0 & 3.3 & - & - \\
\hline 0.25 & 4.3 & 3.3 & 5.6 & 3.9 \\
\hline
\end{tabular}

Between brackets the particle size as determined with TEM analysis

As can be observed in Table 1, the air calcination treatment yields a significantly larger $\mathrm{Co}_{3} \mathrm{O}_{4}$ crystallite size for the unpromoted catalyst as compared to that obtained after calcination in a flow of $\mathrm{NO} / \mathrm{He}$. This shows the beneficial impact of $\mathrm{NC}$ on the $\mathrm{Co}_{3} \mathrm{O}_{4}$ crystallite size, which is in line with previous findings $[5,6,31]$.

For the MnO-promoted catalysts, a smaller difference in $\mathrm{Co}_{3} \mathrm{O}_{4}$ crystallite size after either $\mathrm{AC}$ or $\mathrm{NC}$ was observed. Nevertheless, a decrease in crystallite size is observed for both NC and AC catalysts after the addition of a small amount of $\mathrm{MnO}(\mathrm{Mn} / \mathrm{Co}=0.06 \mathrm{at} / \mathrm{at})$ as compared to their unpromoted counter parts. From Table 1 it can moreover be concluded that the crystallite sizes of the $\mathrm{Co} / \mathrm{MnO} / \mathrm{Pt} / \mathrm{SiO}_{2}$ $\mathrm{NC}$ samples are not influenced by the amount of $\mathrm{MnO}$, whereas the $\mathrm{Co}_{3} \mathrm{O}_{4}$ crystallites of the $\mathrm{AC}$ samples showed continuously a decreasing size with increasing $\mathrm{MnO}$ content. It should be noted though that the co-impregnation method is expected to yield mixed CoMn-oxides after calcination. As the $\mathrm{Mn}^{2+}$ ions possibly affect the stacking in the cobalt oxide crystals, domain sizes rather than crystallite sizes will be detected with XRD. This suggests that from $\mathrm{XRD}$ we will underestimate the crystallite sizes. In all cases no diffraction lines of $\mathrm{MnO}$ were detected. Please note it was assumed that the passivated catalyst contains $\mathrm{Mn}$ in a $2^{+}$oxidation state only, based on e.g., a study by Morales et al. on $\mathrm{Co} / \mathrm{MnO} / \mathrm{TiO}_{2}$ catalysts. [17].

\subsection{TEM}

TEM analysis from reduced $\left(450{ }^{\circ} \mathrm{C}\right)$ and passivated catalysts was used to investigate the cobalt particle size and distribution in more detail.

From Fig. 1a, c showing TEM images of unpromoted $\mathrm{AC}$ and $\mathrm{NC} \mathrm{Co} / \mathrm{Pt} / \mathrm{SiO}_{2}$ catalysts, respectively, it was concluded that a significantly higher cobalt dispersion is obtained with NO calcination as compared to air calcination. This confirms the XRD results ( $c f$. Table 1). Moreover, clustering of cobalt particles is observed in the case 


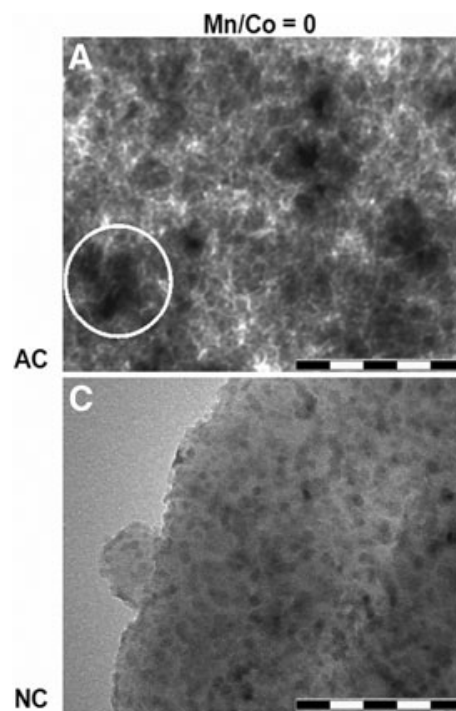

Fig. 1 TEM pictures of reduced $\left(450{ }^{\circ} \mathrm{C}\right)$ and passivated $\mathrm{AC}$ $\mathrm{Co}(/ \mathrm{MnO}) / \mathrm{Pt} / \mathrm{SiO}_{2}$ catalysts with $\mathrm{Mn} / \mathrm{Co}$ ratios of 0 (a) and 0.25 (b) and $\mathrm{NC} \mathrm{Co}(/ \mathrm{MnO}) / \mathrm{Pt} / \mathrm{SiO}_{2}$ catalysts with $\mathrm{Mn} / \mathrm{Co}$ ratios of $0(\mathbf{c})$,
$\mathrm{Mn} / \mathrm{Co}=0.06$

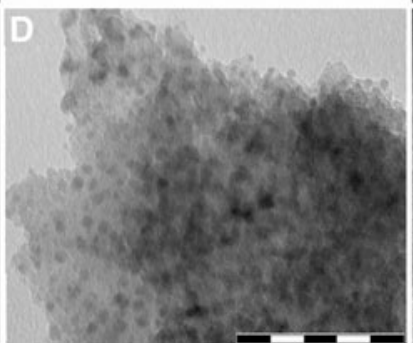

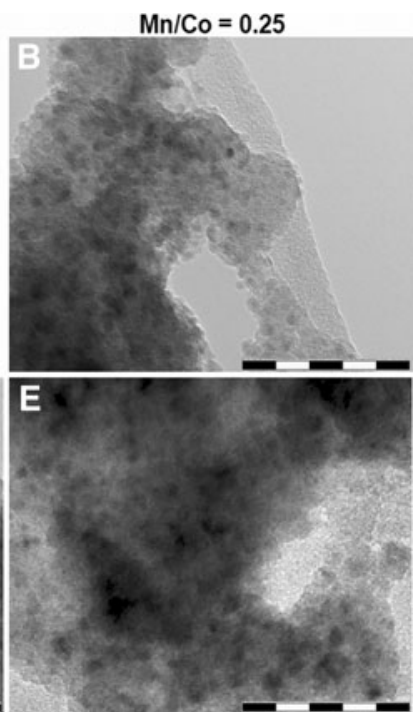

0.06 (d) and 0.25 (e). The scale bar represents $50 \mathrm{~nm}$. The white circle in a indicates clustering of Co particles

ratio of 0.08 at/at (vide infra) prepared via $\mathrm{NO}$ calcination was investigated along with the corresponding air calcined sample.

In Fig. 2 composite maps of energy selected STEM images of a NO and AC sample, each measured at two spots on the sample, are shown with the spatially resolved integrated EELS intensities for oxygen, cobalt and manganese. STEM images with integrated EELS intensities for the individual elements are provided in the supplementary information.

From these images it can be concluded that a higher cobalt dispersion is obtained for the $\mathrm{NC}$ catalyst than for the AC catalysts, which confirms the XRD and TEM results (vide supra). Moreover, the dispersion of $\mathrm{MnO}$ has increased significantly upon NO calcination. Whereas relatively large particles of $\mathrm{MnO}$ (up to $4 \mathrm{~nm}$ ) are formed after air calcination, often present close to the Co particles, the NO calcination seems to yield a homogeneous distribution of $\mathrm{MnO}$ over both the cobalt and the silica surface.

\subsection{XANES}

X-ray absorption spectroscopy was applied to investigate the degree of reduction. These experiments were conducted at liquid nitrogen temperature, after an in situ reduction treatment. The XANES part of these measurements on various $\mathrm{Co}(/ \mathrm{MnO}) / \mathrm{Pt} / \mathrm{SiO}_{2}$ catalysts, together with $\mathrm{Co}$ foil and a $\mathrm{CoO}$ reference sample, is shown in Fig. 3.

Using linear combination analysis of $\mathrm{CoO}$ and $\mathrm{Co}$ foil reference samples, the degrees of reduction of the in situ reduced $\mathrm{AC}$ and $\mathrm{NC}$ catalysts were determined, and are listed in Table 2. 
Fig. 2 STEM-EELS analysis for reduced $\left(450{ }^{\circ} \mathrm{C}\right)$ and passivated $\mathrm{AC}$ (a) and $\mathrm{NC}$ (b) $\mathrm{Co} / \mathrm{MnO} / \mathrm{Pt} / \mathrm{SiO}_{2}$ catalysts $(\mathrm{Mn} / \mathrm{Co}=0.08 \mathrm{at} / \mathrm{at})$, each at two different spots on the samples. The colors indicate the elements oxygen (green), cobalt (red) and manganese (blue). The scale bar represents $5 \mathrm{~nm}$
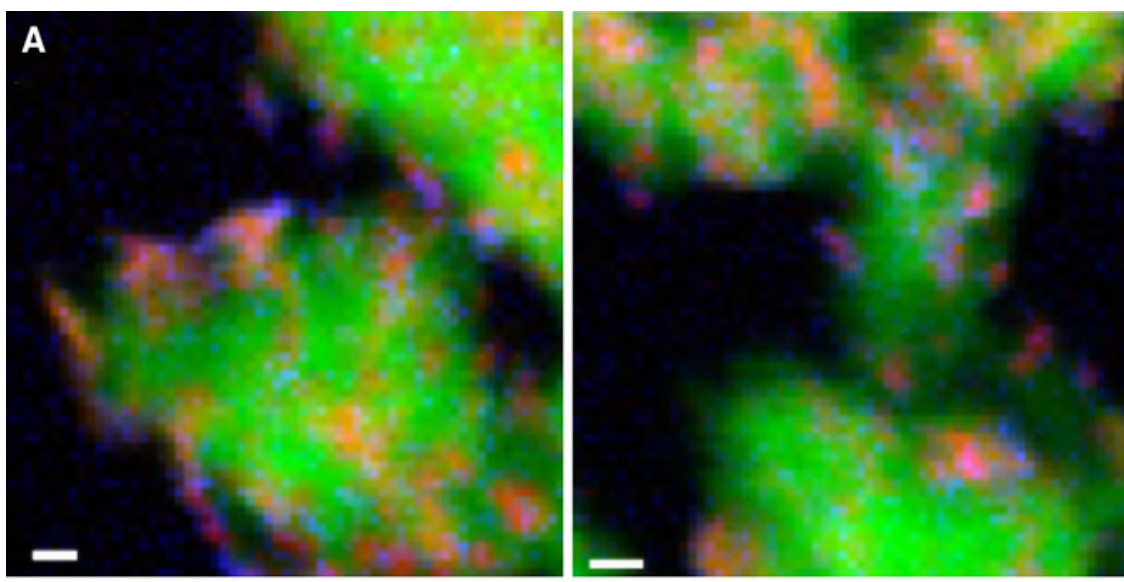

AC
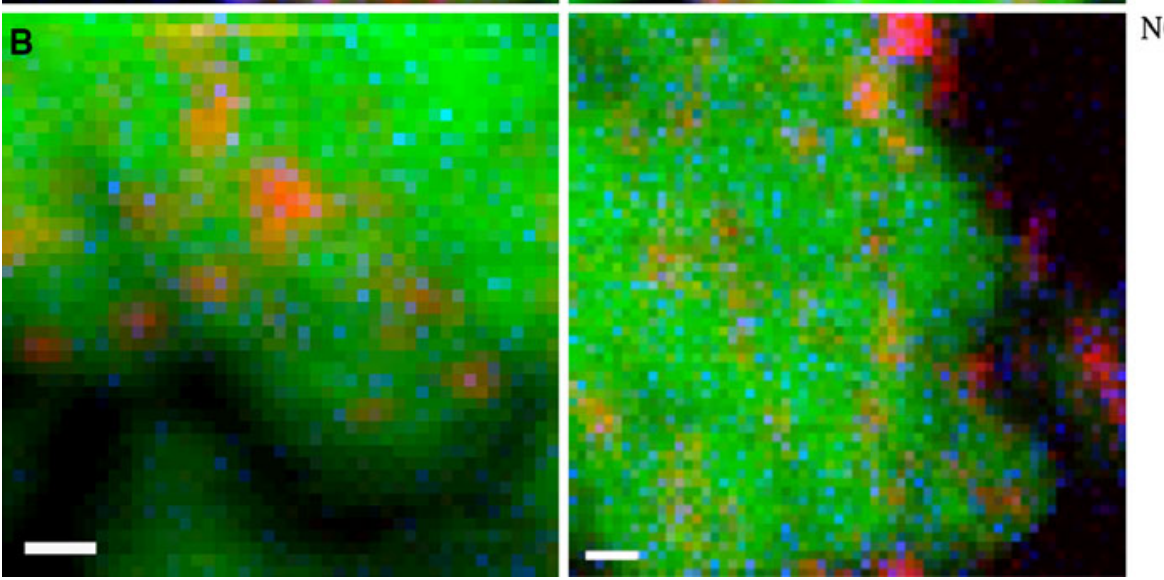

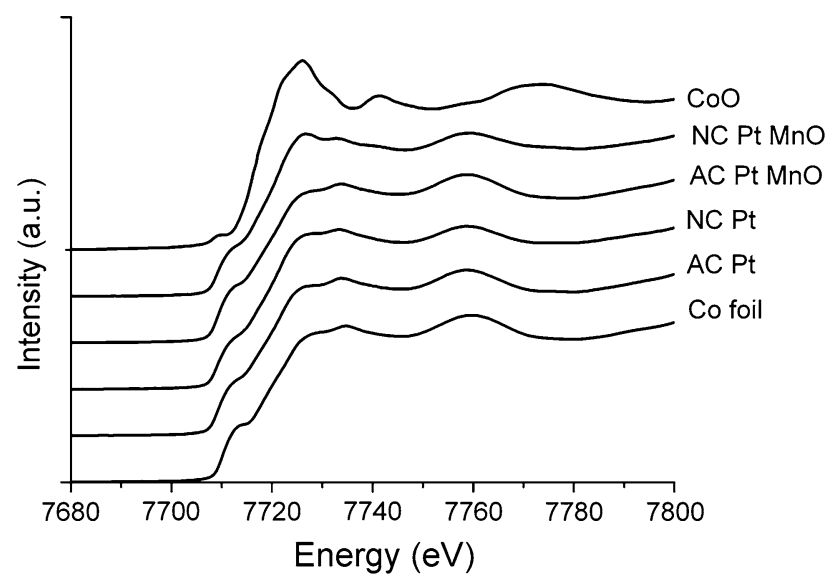

Fig. 3 XANES spectra from in situ reduced $\left(450{ }^{\circ} \mathrm{C}\right)$ catalysts and the reference samples $\mathrm{CoO}$ and $\mathrm{Co}$ foil

From this table it is concluded that high degrees of reduction are obtained at $450{ }^{\circ} \mathrm{C}$ for both the $\mathrm{AC}$ and $\mathrm{NC}$ sample without $\mathrm{MnO}$. Complete reduction is also achieved for the $\mathrm{AC}$ catalyst containing $\mathrm{MnO}(\mathrm{Mn} / \mathrm{Co}=0.08 \mathrm{at} / \mathrm{at})$. The small Co particles prepared via NO calcination, however, show a $62 \%$ degree of reduction only. Yet, this value increased to $82 \%$ after 2 h of FT synthesis (data not shown). The lower degree of reduction might be attributed to the
Table 2 Degrees of reduction of $\mathrm{Co}(/ \mathrm{MnO}) / \mathrm{Pt} / \mathrm{SiO}_{2}$ catalysts as obtained from XANES analysis

\begin{tabular}{llll}
\hline Catalyst & Calcination & $\begin{array}{l}\text { Reduction } \\
\text { temperature }\left({ }^{\circ} \mathrm{C}\right)\end{array}$ & $\begin{array}{l}\text { Degree of } \\
\text { reduction }(\%)\end{array}$ \\
\hline $\mathrm{CoPt}$ & Air & 450 & $96 \pm 5$ \\
$\mathrm{CoPt}$ & NO & 450 & $96 \pm 5$ \\
$\mathrm{CoPtMnO} *$ & Air & 450 & $94 \pm 5$ \\
$\mathrm{CoPtMnO}^{*}$ & NO & 450 & $62 \pm 5$ \\
\hline
\end{tabular}

$* \mathrm{Mn} / \mathrm{Co}=0.08$ at $/ \mathrm{at}$

retarding effect of $\mathrm{MnO}$ on the extent of reduction, as has been shown earlier e.g., for $\mathrm{Co} / \mathrm{MnO} / \mathrm{TiO}_{2}$ catalysts [16].

\subsection{FT catalysis}

In a first series of catalysis experiments, the effect of $\mathrm{Mn}$ / Co ratio on the FT performance was studied. The catalysts were reduced at $550{ }^{\circ} \mathrm{C}$ to reach a degree of reduction close to $100 \%$ (vide supra).

For the $\mathrm{CoPt} / \mathrm{SiO}_{2}$ catalysts (no $\mathrm{MnO}$ present) the activity difference between $\mathrm{NC}$ and $\mathrm{AC}$ treatments is limited, and smaller than reported before [6]. Clearly, the reduction temperature applied $\left(550{ }^{\circ} \mathrm{C}\right)$ is not optimal for the $\mathrm{NC}$ catalyst and reduction at $450{ }^{\circ} \mathrm{C}$ has been used before [6]. 
Fig. 4 Effect Mn/Co ratio on activity (a) and selectivity (b) for $\mathrm{AC}$ and $\mathrm{NC} \mathrm{Co}(/ \mathrm{MnO}) /$ $\mathrm{Pt} / \mathrm{SiO}_{2}$ catalysts reduced at $550{ }^{\circ} \mathrm{C}$
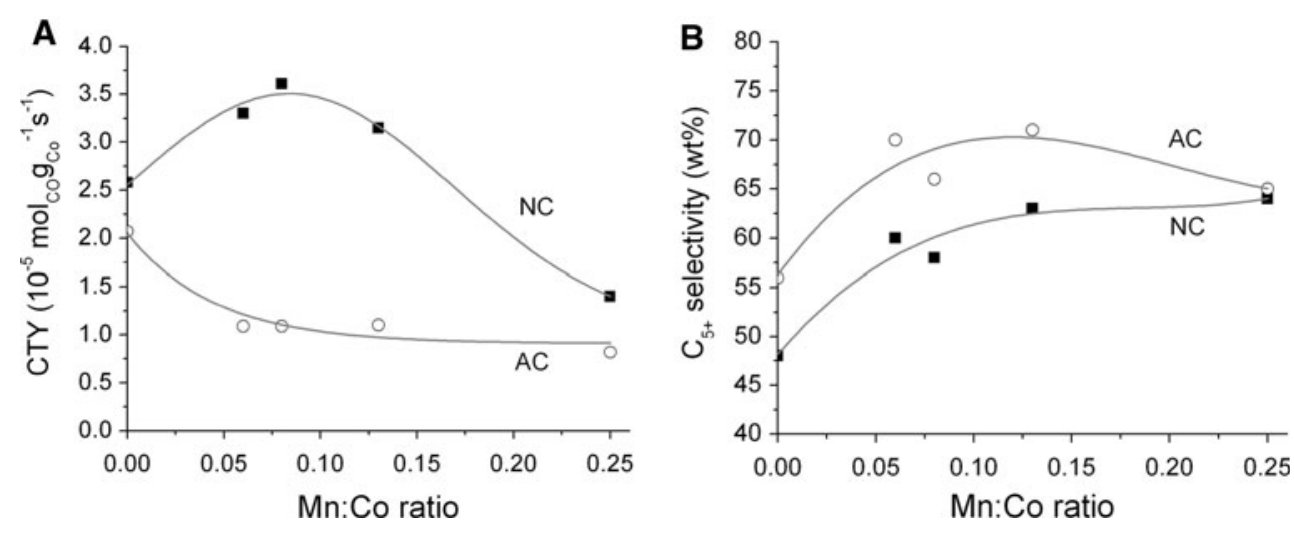

Fig. 5 Effect of the reduction temperature on activity and selectivity for (a) the $\mathrm{NC}$ $\mathrm{Co} / \mathrm{MnO} / \mathrm{Pt} / \mathrm{SiO}_{2}$ catalyst $(\mathrm{Mn} / \mathrm{Co}=0.08$ at $/ \mathrm{at})$ and (b) the $\mathrm{NC} \mathrm{Co} / \mathrm{Pt} / \mathrm{SiO}_{2}$ catalyst
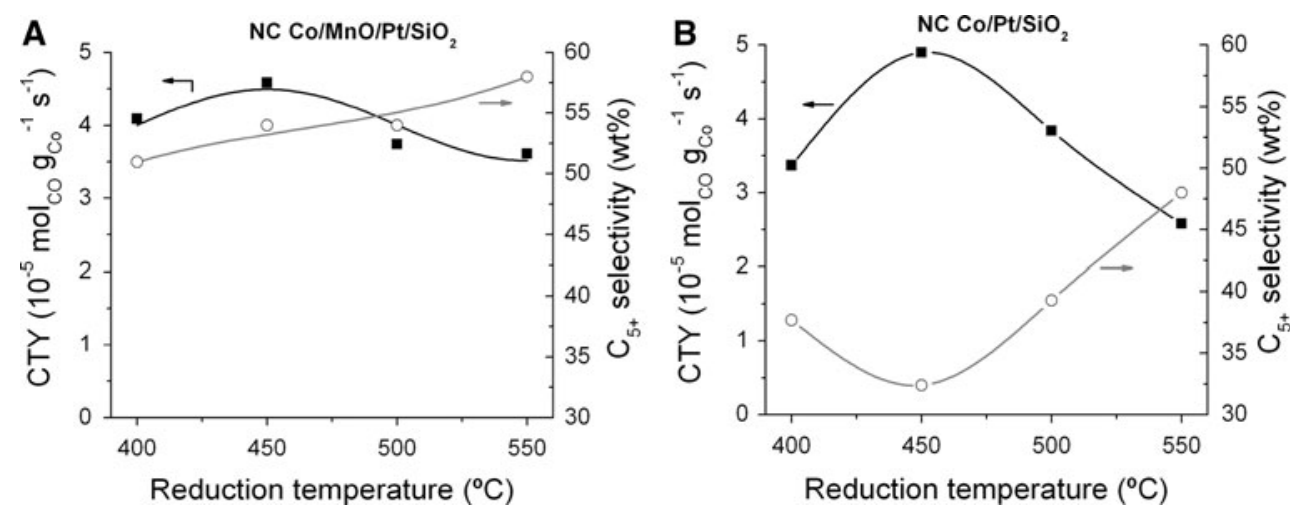

For the $\mathrm{NC}$ catalyst reduced at $550{ }^{\circ} \mathrm{C}$ it can be concluded that the addition of $\mathrm{MnO}$ up to $\mathrm{Mn} / \mathrm{Co}=0.08$ brings about an increase of both activity (Fig. 4a) and selectivity (Fig. 4a). For larger amounts of $\mathrm{MnO}(\mathrm{Mn} /$ $\mathrm{Co}>0.13)$ slightly higher $\mathrm{C}_{5+}$-selectivity values were found, however at a significant expense of the activity. This might be due to blockage of the cobalt surface [21] and/or a lower degree of reduction due to the reduction-retarding effect of $\mathrm{MnO}$ [16].

For the AC catalyst it was found that the addition of a small amount of $\mathrm{MnO}$ caused a decrease in activity, which value even further decreased for higher $\mathrm{Mn} / \mathrm{Co}$ ratios. This might be due to blocking of the cobalt surface by $\mathrm{MnO}$ [21]. Nevertheless, the beneficial effect of $\mathrm{MnO}$ is reflected in the increase in $\mathrm{C}_{5+}$-selectivity, and an increase in $\mathrm{Mn} / \mathrm{Co}$ atomic ratio from 0 to 0.25 was accompanied with an increase in $\mathrm{C}_{5+}$-selectivity from 56 to $70 \mathrm{wt} \%$.

For the NC catalyst with the optimum amount of $\mathrm{MnO}$ $(\mathrm{Mn} / \mathrm{Co}=0.08 \mathrm{at} / \mathrm{at})$, the effect of reduction temperature was investigated (Fig. 5a). For comparison, the effect of reduction temperature on the performance of the $\mathrm{NC} \mathrm{Co} / \mathrm{Pt} /$ $\mathrm{SiO}_{2}$ catalyst without $\mathrm{MnO}$ was included (Fig. 5b).

From Fig. 5a it can be concluded that for $\mathrm{NC} \mathrm{Co} / \mathrm{MnO} /$ $\mathrm{Pt} / \mathrm{SiO}_{2}$ a slight increase in $\mathrm{C}_{5+}$-selectivity is obtained with an increase in reduction temperature. For the activity a shallow optimum temperature of $450{ }^{\circ} \mathrm{C}$ is found. The lower activities obtained at high reduction temperatures $\left(>450{ }^{\circ} \mathrm{C}\right)$ might be due to sintering.

For the unpromoted $\mathrm{NC} \mathrm{Co} / \mathrm{Pt} / \mathrm{SiO}_{2}$ catalyst (Fig. 5b), an initial increase in activity with increasing reduction temperature is shown. At high temperatures $\left(>450{ }^{\circ} \mathrm{C}\right)$ however, a significant drop in activity is observed, which is attributed to sintering concluding from additional XRD results. It is interesting to note that the drop in activity at too high reduction temperatures $\left(<450{ }^{\circ} \mathrm{C}\right)$ is larger for the $\mathrm{Co} / \mathrm{Pt} / \mathrm{SiO}_{2}$ catalyst as compared to the $\mathrm{Co} / \mathrm{MnO} / \mathrm{Pt} / \mathrm{SiO}_{2}$ catalyst. This might indicate that the presence of $\mathrm{MnO}$ promoter inhibits sintering of the Co particles during reduction. For the $\mathrm{Co} / \mathrm{Pt} / \mathrm{SiO}_{2}$ catalyst relatively low $\mathrm{C}_{5+^{-}}$ selectivities were found, although higher values (up to 48 wt $\%)$ were obtained at higher $\left(>450{ }^{\circ} \mathrm{C}\right)$ reduction temperatures possibly related to the presence of larger $\mathrm{Co}$ particles [2-4].

From the comparison of the $\mathrm{NC} \mathrm{Co} / \mathrm{Pt} / \mathrm{SiO}_{2}$ and $\mathrm{NC} \mathrm{Co} /$ $\mathrm{MnO} / \mathrm{Pt} / \mathrm{SiO}_{2}$ catalysts reduced at their optimum reduction temperature $\left(450{ }^{\circ} \mathrm{C}\right)$ to obtain maximum activity it can be concluded that a significant increase in $\mathrm{C}_{5+}$-selectivity (from $32 \mathrm{wt} \%$ to $54 \mathrm{wt} \%$ ) is achieved by the addition of MnO. Most notably, the highest activity $\left(4.6 \cdot 10^{-5} \mathrm{~mol}-\right.$ $\mathrm{CO} \cdot \mathrm{g}_{\mathrm{Co}}^{-1} \mathrm{~s}^{-1}$ ) found for the $\mathrm{MnO}$ promoted catalyst is close 
to the value of $4.9 \cdot 10^{-5} \mathrm{~mol}_{\mathrm{CO}} \cdot \mathrm{g}_{\mathrm{Co}}^{-1} \mathrm{~s}^{-1}$ obtained for the unpromoted catalyst, $c f$ Fig. 5b. Moreover, this relatively high activity of the $\mathrm{MnO}$ promoted catalyst is obtained for Co particle sizes $(\sim 4 \mathrm{~nm})$ smaller than the optimum particle size $(\sim 5 \mathrm{~nm})[6]$, and hence a significantly lower activity was expected. This might indicate that the $\mathrm{MnO}$ promoted catalysts do not show a cobalt particle size effect identical to that of unpromoted catalyst [6], possibly caused by a different Co surface structure or particle shape. However, it might also indicate that manganese oxide acts both as selectivity and activity promoter [32], thereby boosting the performance of small Co particles.

\subsection{IR Spectroscopy}

IR spectroscopy of adsorbed carbon monoxide was applied to investigate the effect of $\mathrm{MnO}$ on the nature of the cobalt surface of $\mathrm{NC} \mathrm{Co}(/ \mathrm{MnO}) / \mathrm{Pt} / \mathrm{SiO}_{2}$ catalysts. As $\mathrm{CO}$ can bind to the cobalt surface in a linear, bridged and multiplebridged form, which all have a characteristic vibrational frequency in the infrared region, detailed information about the structure and electronic properties of the surface sites can possibly be obtained [22, 33, 34]. In this study, NOcalcined $\mathrm{Co} / \mathrm{MnO} / \mathrm{Pt} / \mathrm{SiO}_{2}$ catalysts with a $\mathrm{Mn} / \mathrm{Co}$ atomic ratio of $0,0.08$ and 0.13 were investigated as well as aircalcined $\mathrm{Co} / \mathrm{Pt} / \mathrm{SiO}_{2}$. Prior to the IR measurements, the passivated catalyst samples were re-reduced in situ at $450{ }^{\circ} \mathrm{C}$ (see details in experimental). $\mathrm{CO}$ was adsorbed at ambient temperatures.

Figure 6 shows the region of the $\mathrm{CO}$ vibrations in the IR spectra. Small bands developed at 2,180 and $2,126 \mathrm{~cm}^{-1}$ are assigned to gaseous $\mathrm{CO}$ [22]. For the air and NO calcined $\mathrm{Co} / \mathrm{Pt} / \mathrm{SiO}_{2}$, bands at 2,057 and $1,892 \mathrm{~cm}^{-1}$ are found, which are indicative for linear and bridged bonded $\mathrm{CO}$ on metallic cobalt particles, respectively [35]. From the peak areas it can be concluded that the amount of adsorbed $\mathrm{CO}$ on the NC catalyst is almost twice as high as on the AC catalyst, which is due to the enhanced Co dispersion. Moreover, a two times higher linear:bridge ratio of

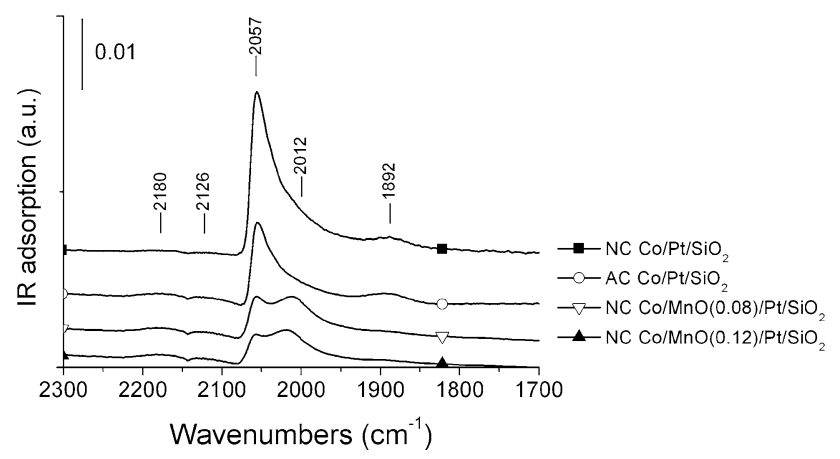

Fig. 6 Transmission IR with $\mathrm{CO}$ adsorption $\left(30^{\circ} \mathrm{C}, 30 \mathrm{~min}\right.$, $350 \mathrm{mbar} 10 \mathrm{vol} \% \mathrm{CO}$ in $\mathrm{He}$ ) adsorbed $\mathrm{CO}$ is found for the $\mathrm{NC}$ catalyst, which might be ascribed to a higher fraction of edge and corner sites at the surfaces of the small cobalt particles in the NC sample than present at the larger particles of the AC sample. A similar effect has been observed for adsorption of $\mathrm{CO}$ on a defect rich Co (0001) surface, where a lower quantity of bridgebonded $\mathrm{CO}$ was found as compared to the amount present on an annealed surface with a low amount of defects [36].

The presence of $\mathrm{MnO}$ in the $\mathrm{NC}$ samples induced a significant change in both the $\mathrm{CO}$ coverage and bonding mode. This proves the close interaction of the Co particles and $\mathrm{MnO}$ promoter. The lower IR absorption signal indicates a lower amount of $\mathrm{CO}$ adsorbed on the manganese promoted catalysts, probably due to blocking of part of the Co surface by $\mathrm{MnO}$ [21]. Moreover, next to the peak at $2,057 \mathrm{~cm}^{-1}$, a second distinct peak of linearly bonded $\mathrm{CO}$ is observed at around $2,012 \mathrm{~cm}^{-1}$ region. Whereas the first peak $\left(2,057 \mathrm{~cm}^{-1}\right)$ is ascribed to $\mathrm{CO}$ adsorption on fcc cobalt [37], the latter peak has been attributed to the linear adsorption of $\mathrm{CO}$ on low-index surface crystallographic planes or corners and steps sites with coordinatively unsaturated sites [4, 38, 39]. This indicates that MnOpromoted catalysts exhibit a different cobalt surface structure as compared to unpromoted catalysts.

For the $\mathrm{AC} \mathrm{Co} / \mathrm{Pt} / \mathrm{SiO}_{2}$ and the $\mathrm{MnO}$ promoted $\mathrm{NC}$ catalysts higher $\mathrm{C}_{5+}$-selectivities were found as compared to the $\mathrm{C}_{5+}$-selectivity of the $\mathrm{NC} \mathrm{Co} / \mathrm{Pt} / \mathrm{SiO}_{2}$ catalyst. Since the $\mathrm{AC}$ catalyst shows a higher amount of bridged-bonded $\mathrm{CO}$ and the $\mathrm{MnO}$ promoted catalysts possibly show a different surface structure as compared to $\mathrm{NC} \mathrm{Co} / \mathrm{Pt} / \mathrm{SiO}_{2}$, it might be concluded that the $\mathrm{C}_{5+}$-promoting effect of either a relatively larger Co size (AC sample) or the presence of $\mathrm{MnO}$ has a different origin.

\subsection{SSITKA}

Isotopic switches $\left({ }^{12} \mathrm{CO} /{ }^{13} \mathrm{CO}\right.$ and $\left.\mathrm{H}_{2} / \mathrm{D}_{2}\right)$ were applied to study the amount and residence times of various FT surface intermediates. First the carbon intermediates were investigated by a switch from ${ }^{12} \mathrm{CO} / \mathrm{Ar} / \mathrm{H}_{2}$ to ${ }^{13} \mathrm{CO} / \mathrm{Kr} / \mathrm{H}_{2}$ after reaching steady-state conversion at $210{ }^{\circ} \mathrm{C}, \mathrm{H}_{2} / \mathrm{CO}=10$ $\mathrm{v} / \mathrm{v}$ and 1.85 bar. This was followed by a back-switch, after reaching an isotopic steady-state. From this back-switch, the residence times of $\mathrm{CO}$ and $\mathrm{CH}_{x}$ were calculated. In this case the $\mathrm{CH}_{x}$ intermediates represent the surface species which eventually produce $\mathrm{CH}_{4}$. A detailed description of the transient analyses has been published elsewhere [30]. For $\mathrm{AC} \mathrm{Co} / \mathrm{Pt} / \mathrm{SiO}_{2}$ and $\mathrm{NC} \mathrm{Co}(/ \mathrm{MnO}) / \mathrm{Pt} / \mathrm{SiO}_{2}$ with $\mathrm{Mn} / \mathrm{Co}$ atomic ratios of $0,0.08$ and 0.25 reduced at $450{ }^{\circ} \mathrm{C}$, the amounts $(\mathrm{N})$ of $\mathrm{CO}$ and $\mathrm{CH}_{x}$ bonded to the cobalt surface were calculated using the residence times and gas flows. (Table 3) Since part of the surface might be blocked by $\mathrm{MnO}$, as the IR $\mathrm{CO}$ adsorption measurements suggest, 
Table 3 Residence times and amounts of $\mathrm{CO}$ and $\mathrm{CH}_{x}$ intermediates obtained for an $\mathrm{AC} \mathrm{Co} / \mathrm{Pt} / \mathrm{SiO}_{2}$ and $\mathrm{NC} \mathrm{Co}(/ \mathrm{MnO}) / \mathrm{Pt} / \mathrm{SiO} \mathrm{O}_{2}$ catalysts with various $\mathrm{Mn} / \mathrm{Co}$ ratios

\begin{tabular}{llllclcl}
\hline & $\mathrm{Mn} / \mathrm{Co}$ ratio (at/at) & $\tau_{\mathrm{CO}}(\mathrm{s})$ & $\tau_{\mathrm{CH} x, \text { corr }}^{\mathrm{a}}(\mathrm{s})$ & $\mathrm{N}_{\mathrm{CO}}\left(\mathrm{mmol} / \mathrm{g}_{\text {cat }}\right)$ & $\mathrm{N}_{\mathrm{CH} x}\left(\mathrm{mmol} / \mathrm{g}_{\text {cat }}\right)$ & $\theta_{\mathrm{CH} x}^{\mathrm{b}}$ & $\mathrm{TOF}_{\text {calc }}^{\mathrm{c}}\left(10^{-3} \mathrm{~s}^{-1}\right)$ \\
\hline $\mathrm{AC}$ & 0 & 12 & 8.5 & 91 & 25 & 26 & 0.14 \\
$\mathrm{NC}$ & 0 & 24 & 4.3 & 174 & 32 & 0.07 & 13 \\
& 0.08 & 18 & 5.5 & 97 & 31 & 0.17 & 22 \\
& 0.25 & 9.9 & 7.9 & 76 & 0.19 & 17 \\
\hline
\end{tabular}

Included are calculated $\mathrm{CH}_{x}$ and $\mathrm{CO}$ coverages and the TOF

${ }^{\mathrm{a}}$ Corrected via: $\tau_{\mathrm{CHx} \text { s corr }}=\tau_{\mathrm{CH} 4}-0.5 \tau_{\mathrm{CO}}$ [45]; ${ }^{\mathrm{b}}$ calculated as $\mathrm{N}_{\mathrm{CHx}} / 2 \mathrm{~N}_{\mathrm{CO}} ;{ }^{c}$ calculated assuming $\mathrm{TOF}_{\text {calc }}=\left(\theta_{\mathrm{CH} x} / \tau_{\mathrm{CH} x \text {, corr }}\right)$ [3]

the determination of the number of Co surface sites via the cobalt dispersion is cumbersome. Hence, the $\mathrm{CO}$ and $\mathrm{CH}_{x}$ surface coverage on the promoted catalysts could not be calculated. Based on previous SSITKA studies using $\mathrm{Co} /$ CNF catalysts $[3,30]$ however, it was assumed that the number of cobalt surface sites equals two times the number of reversibly bonded $\mathrm{CO}$. This allowed to calculate the $\mathrm{CH}_{x}$ and $\mathrm{CO}$ coverage via $\theta_{\mathrm{CH} x \text { or } \mathrm{CO}}=\mathrm{N}_{\mathrm{CH} x \text { or } \mathrm{CO}} /\left(2 \mathrm{~N}_{\mathrm{CO}}\right)$.

Table 3 shows that the residence time and amount of reversibly adsorbed $\mathrm{CO}$ on the $\mathrm{NC} \mathrm{Co} / \mathrm{Pt} / \mathrm{SiO}_{2}$ catalyst is twice as high as compared to the amount of $\mathrm{CO}$ on its aircalcined counterpart. This is in line with the IR results (vide supra) and is ascribed to the two times higher Co surface area per gram of catalyst.

For the $\mathrm{CH}_{x}$ intermediate, both a lower residence time and surface coverage was found for the $\mathrm{NC} \mathrm{Co} / \mathrm{Pt} / \mathrm{SiO}_{2}$ catalyst as compared to its AC counterpart. However, upon $\mathrm{MnO}$ addition, an increase in residence time and coverage of $\mathrm{CH}_{x}$ intermediates was observed with increasing $\mathrm{Mn} / \mathrm{Co}$ ratio, which is in line with findings by Vada et al. using $\mathrm{LaO}_{x}$ promotion for a $\mathrm{Co} / \mathrm{Al}_{2} \mathrm{O}_{3}$ catalyst [40]. At the same time, both a decrease in the residence time and amount of reversibly adsorbed $\mathrm{CO}$ was observed. It is interesting to note that also for $\mathrm{ZrO}_{x}$ promoted $\mathrm{Co} / \mathrm{Al}_{2} \mathrm{O}_{3}$ catalysts an increase in $\mathrm{CH}_{x}$-coverage and TOF is observed upon addition of the $\mathrm{Zr}$ promoter [41, 42]. However, in this case no change in $\mathrm{CO}$ coverage is observed.

From the $\mathrm{CH}_{x}$ coverage and residence time, and assuming pseudo first-order kinetics, the TOF was calculated (Table 3) [3]. The obtained values show a similar surface-specific activity for the AC and $\mathrm{NC} \mathrm{Co} / \mathrm{Pt} / \mathrm{SiO}_{2}$ catalyst. Interestingly, for the $\mathrm{MnO}$ promoted catalysts a higher calculated TOF was found, which indicates that $\mathrm{MnO}$ also acts as an activity promoter. This is also in line with findings for $\mathrm{ZrO}_{x}$-promoted catalysts [41-43]. This might explain the fact that a higher selectivity of the $\mathrm{MnO}$ promoted NC samples was found, without showing a significant loss in activity.

In order to provide a qualitative understanding of the higher $\mathrm{C}_{5+}$-selectivity of the $\mathrm{MnO}$ promoted catalysts and the air-calcined $\mathrm{Co} / \mathrm{Pt} / \mathrm{SiO}_{2}$ catalysts, the $\mathrm{CH}_{x}$ coverage

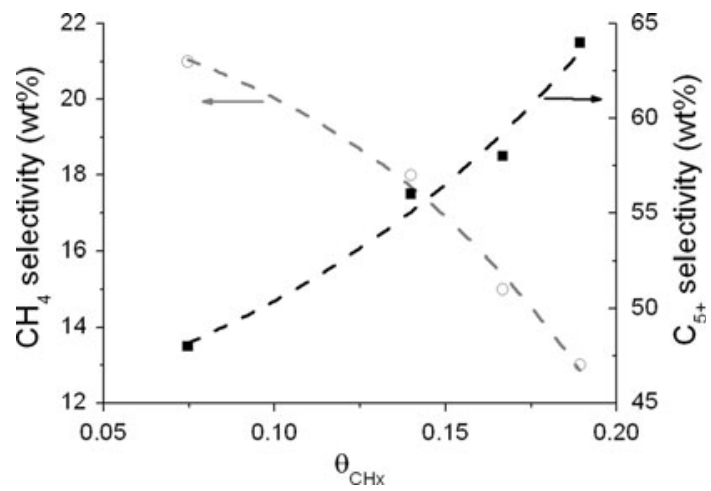

Fig. $7 \mathrm{CH}_{4}$ - and $\mathrm{C}_{5+}$-selectivities of $\mathrm{Co}(\mathrm{MnO}) / \mathrm{Pt} / \mathrm{SiO}_{2}$ catalysts as a function of the $\mathrm{CH}_{x}$ surface coverage

$\left(\mathrm{H}_{2} / \mathrm{CO}=10,210^{\circ} \mathrm{C}, 1.85\right.$ bar $)$ was plotted versus the $\mathrm{CH}_{4}$ and $\mathrm{C}_{5+}$-selectivities both determined via $\mathrm{GC}$ analyses $\left(\mathrm{H}_{2} / \mathrm{CO}=2,220{ }^{\circ} \mathrm{C}, 1\right.$ bar $)$ in Fig. 7.

In this figure a clear trend of increasing $\mathrm{C}_{5+}$-selectivity and decreasing $\mathrm{C}_{1}$-selectivity with increasing $\mathrm{CH}_{x}$ coverage is visible. These trends in selectivity might be rationalized by a higher $\mathrm{C}-\mathrm{C}$ coupling probability with higher $\mathrm{CH}_{x}$ coverages leading to a higher $\mathrm{C}_{5+^{-}}$and lower $\mathrm{C}_{1^{-}}$ selectivity [44].

\section{Conclusions}

In this paper the effect of $\mathrm{MnO}$ addition on the activity and $\mathrm{C}_{5+}$-selectivity in FT synthesis was studied for $\mathrm{Co} / \mathrm{SiO}_{2}$ catalysts calcined in a flow of air or $1 \mathrm{vol} \% \mathrm{NO} / \mathrm{He}$. For the $\mathrm{NO}$ calcined (NC) $\mathrm{Co} / \mathrm{Mn} / \mathrm{Pt} / \mathrm{SiO}_{2}$ catalysts a significantly smaller average Co size was found as compared to the air calcined samples. Moreover, as STEM-EELS data showed, this was accompanied with a significant increase in $\mathrm{MnO}$ dispersion. This indicates that calcination in $\mathrm{NO} / \mathrm{He}$ can be applied successfully to mixed-nitrate systems. For the NC $\mathrm{Co} / \mathrm{Mn} / \mathrm{Pt} / \mathrm{SiO}_{2}$ catalyst with an optimum $\mathrm{Mn} / \mathrm{Co}$ atomic ratio of 0.08 , an increase in $\mathrm{C}_{5+}$-selectivity from $32 \mathrm{wt} \%$ (unpromoted) to $54 \mathrm{wt} \%$ was found, yet without a significant loss in activity. For air-calcined (AC) $\mathrm{Co} / \mathrm{Mn} / \mathrm{Pt} / \mathrm{SiO}_{2}$ 
high $\mathrm{C}_{5+}$-selectivities (up to $70 \mathrm{wt} \%$ ) were found, although accompanied with moderate activities.

From infrared spectroscopy experiments of adsorbed carbon monoxide it was concluded that $\mathrm{MnO}$ blocked part of the cobalt surface. Moreover, concluding from a lowfrequency band of linearly bonded $\mathrm{CO}$, the presence of $\mathrm{MnO}$ induces the formation of cobalt surfaces with lowindex crystallographic planes or steps and corners with cobalt atoms with a relatively low coordination number as compared to the unpromoted catalysts.

SSITKA results showed a decrease of both the residence time and the amount of adsorbed $\mathrm{CO}$ and an increase in the residence time and coverage of $\mathrm{CH}_{x}$ with increasing $\mathrm{MnO}$ content. Moreover, higher $\mathrm{CH}_{x}$ residence times and coverages were found for the large Co particles $(\sim 10 \mathrm{~nm})$ obtained via air calcination as compared to the smaller ones $(\sim 5 \mathrm{~nm})$ prepared via calcination in $\mathrm{NO} / \mathrm{He}$.

The observed increase in $\mathrm{C}_{5+}$-selectivity for higher $\mathrm{MnO}$ loadings was attributed to the increase in the $\mathrm{CH}_{x}$ coverage, bringing about a higher $\mathrm{C}-\mathrm{C}$ coupling probability.

\section{Supporting information}

High Angle Annular Dark Field (HAADF) images for an $\mathrm{AC}$ and $\mathrm{NC} \mathrm{Co} / \mathrm{Pt} / \mathrm{MnO} / \mathrm{SiO}_{2}$ catalyst $(\mathrm{Mn} / \mathrm{Co}=0.08$ at/ at) together with the spatially resolved EELS intensities for oxygen, cobalt and manganese.

Acknowledgments The authors thank Dr. A. Gloter, Dr. I. Swart and Dr. A. Juhin for their help with and also the Universite de Nord (Paris) for the possibility of performing STEM-EELS measurements. C. van der Spek and Prof. Dr. Ir. J.W. Geus are thanked for the TEM analyses. Scientists from beamline C, HASYLAB synchrotron (I20070099 EC) are thanked for their assistance in the XAS experiments. Shell Global Solutions is acknowledged for financial support.

Open Access This article is distributed under the terms of the Creative Commons Attribution Noncommercial License which permits any noncommercial use, distribution, and reproduction in any medium, provided the original author(s) and source are credited.

\section{References}

1. Barbier A, Tuel A, Arcon I, Kodre A, Martin GA (2001) J Catal 200:106-116

2. Bezemer GL, Bitter JH, Kuipers HPCE, Oosterbeek H, Holewijn JE, Xu X, Kapteijn F, Van Dillen AJ, De Jong KP (2006) J Am Chem Soc 128:3956-3964

3. den Breejen JP, Radstake PB, Bezemer GL, Bitter JH, Frøseth V, Holmen A, de Jong KP (2009) J Am Chem Soc 131:7197-7203

4. Prieto G, Martínez A, Concepción P, Moreno-Tost R (2009) J Catal 266:129-144
5. Sietsma JRA, Meeldijk JD, den Breejen JP, Versluijs-Helder M, van Dillen AJ, de Jongh PE, de Jong KP (2007) Angew Chem Int Ed 46:4547-4549

6. den Breejen JP, Sietsma JRA, Friedrich H, Bitter JH, de Jong KP (2010) J Catal 270:146-152

7. Morales F, Weckhuysen BM (2006) Catalysis (R Soc Chem) 19:1

8. Khodakov AY, Chu W, Fongarland P (2007) Chem Rev 107:1692-1744

9. Anderson RB (1984) The Fischer-Tropsch synthesis. Academic Press, Orlando

10. Oukaci R, Singleton AH, Goodwin JG (1999) Appl Catal A 186:129-144

11. Van Der Riet M, Hutchings GJ, Copperthwaite RG (1986) J Chem Soc, Chem Commun 10:798-799

12. Kanai H, Tan BJ, Klabunde KJ (1986) Langmuir 2:760-765

13. Colley S, Copperthwaite RG, Hutchings GJ, Van Der Riet M (1988) Ind Eng Chem Res 27:1339-1344

14. Zhang JL, Ren J, Chen JG, Sun YH (2002) Acta Phys-Chim Sin 18:260-263

15. Keyser MJ, Everson RC, Espinoza RL (1998) Appl Catal A: Gen 171:99-107

16. Morales F, De Groot FMF, Glatzel P, Kleimenov E, Bluhm H, Honecker M, Knop-Gericke A, Weckhuysen BM (1620) J Phys Chem B 108(2004):1-16207

17. Morales F, De Groot FMF, Gijzeman OLJ, Mens A, Stephan O, Weckhuysen BM (2005) J Catal 230:301-308

18. Morales F, Grandjean D, De Groot FMF, Stephan O, Weckhuysen BM (2005) Phys Chem Chem Phys 7:568-572

19. Duvenhage DJ, Coville NJ (2005) Catal Lett 104:129-133

20. Bezemer GL, Falke U, Van Dillen AJ, De Jong KP (2005) Chem Commun 6:731-733

21. Bezemer GL, Radstake PB, Falke U, Oosterbeek H, Kuipers HPCE, Van Dillen AJ, De Jong KP (2006) J Catal 237:152-161

22. Morales F, de Smit E, de Groot FMF, Visser T, Weckhuysen BM (2007) J Catal 246:91-99

23. Feltes TE, Espinosa-Alonso L, Smit Ed, D’Souza L, Meyer RJ, Weckhuysen BM, Regalbuto JR (2010) J Catal 270:95-102

24. Sietsma JRA, van Dillen AJ, de Jongh PE, de Jong KP.(2006) GB0617529.3

25. Jiang M, Koizumi N, Ozaki T, Yamada M (2001) Appl Catal A: Gen 209:59-70

26. Stéphan O, Gloter A, Imhoff D, Kociak M, Mory C, Suenaga K, Tencé M, Colliex C (2000) Surf Rev Lett 7:475-494

27. van Schooneveld MM, Gloter A, Stephan O, Zagonel LF, Koole R, Meijerink A, Mulder WJM, de Groot FMF (2010) Nat Nanotechnol 5:538

28. Vaarkamp M, Linders JC, Koningsberger DC (1995) Physica B 209:159-160

29. Koningsberger DC, Mojet BL, van Dorssen GE, Ramaker DE (2000) Top Catal 10:143-155

30. Frøseth V, Storsæter S, Borg O, Blekkan EA, Rønning M, Holmen A (2005) Appl Catal A: Gen 289:10-15

31. Jacobs G, Ma W, Ji Y, Khalid S, Davis BH (2008) Prepr Pap-Am Chem Soc, Div Petr Chem 53:80

32. Klabunde KJ, Imizu Y (1984) J Am Chem Soc 106:2721-2722

33. Mojet BL, Miller JT, Koningsberger DC, Phys J (1999) Chem B 103:2724-2734

34. Oosterbeek H (2007) Phys Chem Chem Phys 9:3570

35. Hoffmann FM (1983) Surf Sci Rep 3:107

36. Beitel GA, Laskov A, Oosterbeek H, Kuipers EW (1996) J Phys Chem 100:12494-12502

37. Song D, Li J, Cai Q (2007) J Phys Chem C 111:18970-18979

38. Blyholder G (1964) J Phys Chem 68:2772-2777

39. Rygh LES, Nielsen CJ (2000) J Catal 194:401-409

40. Vada S, Chen B, Goodwin JG (1995) J Catal 153:224-231 
41. Jongsomjit B, Panpranot J, Goodwin JG Jr (2003) J Catal 215:66-77

42. Rohr F, Holmen A, Barbo KK, Warloe P, Blekkan EA (1998) Stud Surf Sci Cat 119:107-112
43. Ali S, Chen B, Goodwin JG Jr (1995) J Catal 157:35-41

44. Bertole CJ, Kiss G, Mims CA (2004) J Catal 223:309-318

45. Biloen P, Helle JN, van den Berg FGA, Sachtler WMH (1983) J Catal 81:450-463 